九州大学学術情報リポジトリ

Kyushu University Institutional Repository

\title{
No Reported Species, Botryt is aclada Causing Gray Mold Neck Rot Disease on Onion Bulbs in Korea
}

Hwang, Sun-Kyoung

College of Agricultural and Life Sciences, Kyungpook National University / Gyeongnam Agricultural Research and Extension Services

Lee, Seung-Yeol

College of Agricultural and Life Sciences, Kyungpook National University

Back, Chang-Gi

College of Agricultural and Life Sciences, Kyungpook National University / National Institute of Horticultural \& Herbal Science, Rural Development Administration

Kang, In-Kyu

College of Agricultural and Life Sciences, Kyungpook National University

他

https://doi.org/10.5109/1685880

出版情報：九州大学大学院農学研究院紀要. 61 (2)，pp.263-266，2016-09-01. Faculty of Agriculture, Kyushu University

バージョン：

権利関係 : 


\title{
No Reported Species, Botrytis aclada Causing Gray Mold Neck Rot Disease on Onion Bulbs in Korea
}

\author{
Sun-Kyoung HWANG ${ }^{1,2}$, Seung-Yeol LEE ${ }^{1}$, Chang-Gi BACK ${ }^{1,3}$, In-Kyu KANG ${ }^{1}$, \\ Hyang-Burm LEE ${ }^{4}$, Hee-Young JUNG ${ }^{1 *}$ and Shoji OHGA*
}

\author{
Laboratory of Forest Resources Management, Division of Agro-environmental Sciences, \\ Department of Forest Environmental Sciences, Faculty of Agriculture, \\ Kyushu University, Sasaguri, Fukuoka 811-2415, Japan \\ (Received April 4, 2016 and accepted May 10, 2016)
}

\begin{abstract}
Gray mold neck rot was observed on onion bulbs (Allium cepa L.) in low-temperature warehouses in Changnyeong-gun, Korea. The causative pathogen was isolated from rotted onion bulb lesions and identified as Botrytis aclada based on morphological and culture characteristics, the sequences of three nuclear genes (G3PDH, HSP60, and RPB2), and polymerase chain reaction-restriction fragment length polymorphism (PCR-RFLP) for Botrytis spp. identification. Although onion gray mold disease caused by B. allii, $B$. cinerea, and $B$. squamosa species has previously been reported in Korea, this, to the best of our knowledge, is the first report of $B$. aclada causing gray mold neck rot disease of onion bulbs in Korea.
\end{abstract}

Key words: Onion bulb, Botrytis aclada, gray mold neck rot

\section{INTRODUCTION}

Onion (Allium cepa L.) is one of the most important commercial vegetable crops in Korea. Annually, more than $40 \%$ of the onions harvested are stored in low-temperature warehouses. However, a considerable portion of the crop is lost during storage because of diseases such as gray mold neck rot caused by Botrytis allii, B. squamosal, and B. cinerea; blue mold caused by Penicillium sp.; Fusarium basal rot caused by Fusarium oxysporum f. sp. cepae; and bacterial bulb rot caused by Pseudomonas marginalis pv. marginalis and Burkholderia cepacia (KSPP 2009; Kim et al., 2001; Lee et al., 2005). Gray mold rot is one of the major storage-related diseases. It has been reported low-temperature storage relate plant such as apple, grape, onion and seeds. However, it is difficult to efficiently control and manage grey mold disease in low-temperature storage facilities. In Korea, onion neck rot disease is reported to be mostly caused by three Botrytis species: B. cinerea, B. allii, and B. squamosa (Lee et al., 2005; Park et al., 1995; Kim et al., 1998) which have worldwide distribution. In 2010, Botrytis sinoallii, a new species on Allium crops, was reported in China. This pathogen occurred on green onion (Allium fistulosum) and garlic chives (Allium tuberosum) (Zhang et al., 2010). Between 2012 and 2013, rotted onion bulbs with gray mold neck rot symptoms were observed in a low-tem-

${ }^{1}$ College of Agricultural and Life Sciences, Kyungpook National University, Daegu 41566, Korea

${ }^{2}$ Gyeongnam Agricultural Research and Extension Services, Changnyeong 50319, Korea

${ }^{3}$ National Institute of Horticultural \& Herbal Science, Rural Development Administration, Wanju-gun 55365, Korea

${ }^{4}$ College of Agriculture and Life Sciences, Chonnam National University, Gwangju 61186, Korea

* Corresponding author (E-mail: ohga@forest.kyushu-u.ac.jp, heeyoung@knu.ac.kr) perature storage facility in Changnyeong-gun, Korea. This study was conducted to identify the causal pathogen based on morphological and culture characteristics, phylogenetic studies, and PCR-RFLP analysis.

\section{MATERIALS AND METHODS}

\section{Fungal collection and isolation}

Onions harvested in early June were stored in warehouse at $0 \sim 1{ }^{\circ} \mathrm{C}$ and $68 \sim 75 \%$ relative humidity. Generally, the primary symptom of gray mold neck rot on stored onions presented after 3 to 4 months of storage. From 2012 to 2013, infected onion bulbs were collected from a storage facility in Changnyeong-gun, after 5 to 8 months of storage. Sections containing lesions were cut from the rotted onion bulbs and transferred onto potato dextrose agar (PDA) plates and cultured at $20^{\circ} \mathrm{C}$ in darkness. Fourteen days after incubation, the isolates were transferred to fresh PDA plates and cultured for identification and determination of pathogenicity.

\section{Pathogenicity test}

To determine pathogenicity, the isolates were cultured on PDA plates for 10 days at $20^{\circ} \mathrm{C}$. The cultured isolates were then suspended in sterile distilled water at a concentration of $1 \times 10^{5}$ conidia/mL, which was determined using a counting chamber (Marienfeld, Germany). Sterile filter paper disks (6 $\mathrm{mm}$ in diameter) soaked in the inoculum were placed on the outer surface of onion bulbs. Control bulbs were treated with sterile filter paper disks soaked in distilled water. The inoculated onion bulbs were placed in sterile plastic containers (30 $\times 10 \times 20 \mathrm{~cm}$ in length, width, and height) containing a paper towel soaked with distilled water to maintain a high humidity $(95 \% \mathrm{RH})$ and incubated for 10 days at $20^{\circ} \mathrm{C}$. 
PCR amplification, phylogenetic study, and PCRRFLP analysis

The isolates were grown in the dark for 7 days at $20^{\circ} \mathrm{C}$ on PDA plates. Genomic DNA was extracted from cultured colonies using an i-genomic BYF DNA extraction kit (INTRON Biotechnology, Korea) according to the manufacturer's instructions. PCR amplification of the internal transcribed spacer (ITS) region was performed using the primer set ITS1F (5'-CTT GGT CAT TTA GAG GAA GTA A-3') and ITS4 (5'-TCC TCC GCT TAT TGA TAT GC-3') using previously described conditions (White et al., 1990). The products were then sequenced. Although ITS region sequences have been widely used for species-level discrimination of fungi, variation in the ITS region within Botrytis is low, limiting its use to genus-level discrimination (Nielsen et al., 2001). Three nuclear protein-coding genes-glyceraldehyde-3-phosphate dehydrogenase $(G 3 P D H)$, heat-shock protein 60 (HSP60), and DNA-dependent RNA polymerase subunit II (RPB2) - were amplified using three sets of primers: G3PDHf (5'-ATT GAC ATC GTC GCT GTC AAC GA-3'), G3PDHr (5'-ACC CCA CTC GTT GTC GTA CCA-3'); HSP60f (5'-CAA CAA TTG AGA TTT GCC CAC AAG-3'), HSP60r (5'-GAT GGA TCC AGT GGT ACC GAG CAT3'); and RPB2f (5'-GAT GAT CGT GAT CAT TTC GG-3'), RPB2r (5'-CCC ATA GCT TGC TTA CCC AT-3'). PCR amplification was performed using previously described conditions (Staats et al., 2005). These three genes, encoding enzymes involved in basic cellular processes, have been used for the identification of closely related Botrytis spp. (Staats et al., 2005). Isolates and reference strains representing seventeen recognized species of Botrytis were included in the phylogenetic analysis (Staats et al., 2005). Sclerotinia sclerotiorum was used as an outgroup. A combined gene sequence data set (G3PDH, HSP6O, and RPB2), and three separate gene sequence data sets (G3PDH, HSP60, and RPB2) were established using the cloned partial gene sequences of GSPDH, HSP6O, and RPB2 reported in a previous study (Staats et al., 2005). Sequence similarities were evaluated using the program GENETYX-WIN version 3.2 (Soft Development, Japan). Phylogenetic analysis was performed using TreeView-Win 32 version 1.6.1, after multiple alignments of data by CLUSTAL W (http://clustalw. ddbj.nig.ac.jp, DNA Data Bank of Japan). Distances and clustering were determined with the neighbor-joining method using the program TreeView (Win32, ver. 1.6.1) (Saitou and Nei, 1987). Nielsen et al. developed sequence characterized amplified region (SCAR) primers (BA2f/ BA1r) of the partial glycosyltransferase gene for the amplification of the DNA of Botrytis species associated with neck rot of onions (Nielsen et al., 2001). Digestion of the PCR amplicons with the restriction enzyme ApoI was used for distinguishing between the DNA of the Botrytis species B. aclada, B. byssoidea, B. squamosa, and B. cinerea (Nielsen et al., 2002). PCR amplification of six isolates and B. cinerea with the Botrytis-specific PCR primers (BA2f/BA1r) gave products. The amplicons were digested with the restriction enzyme ApoI in accordance with the manufacturer's instructions (Nielsen et al., 2002).

\section{RESULTS AND DISCUSSION}

\section{Morphological characteristics and pathogenicity test}

The infected tissues of the bulbs softened and discolored to brown as the decay advanced. The decayed tissues in the rotted bulbs lost firmness and became waterlogged. The upper portions of bulbs sank and gray mycelium and conidia formed on the outer surface of the bulbs (Fig. 1A and 1B). Colonies of isolates were gray or
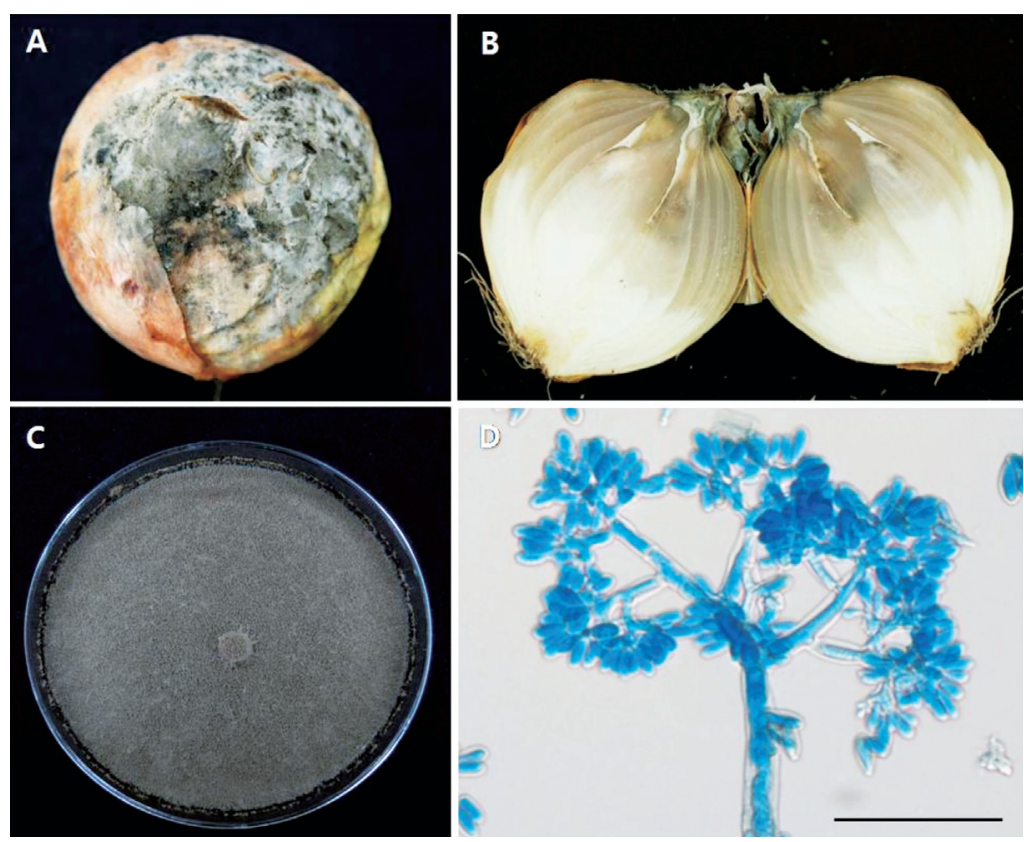

Fig. 1. Symptoms of gray mold neck rot on onion bulbs in storage. A: the outer surface of the bulb shows gray mycelium; B: vertical section of the lesion; C: colonies on PDA after 15 days; D: conidiophores and conidia (scale bar $=50 \mu \mathrm{m}$ ). 
Table 1. Comparison of morphological and culture characteristics of the pathogen isolated from rotted onion bulbs with those of previously described Botrytis species

\begin{tabular}{|c|c|c|c|c|c|c|}
\hline \multirow{2}{*}{\multicolumn{2}{|c|}{ Characteristics }} & \multirow{3}{*}{$\begin{array}{l}\begin{array}{c}\text { Present } \\
\text { isolate }\end{array} \\
\text { ray or grayish } \\
\text { brown }\end{array}$} & \multicolumn{4}{|c|}{ Botrytis species ${ }^{\mathrm{a}}$} \\
\hline & & & \multirow{2}{*}{$\begin{array}{c}\text { B. aclada } \\
\begin{array}{c}\text { Gray or grayish } \\
\text { brown }\end{array}\end{array}$} & \multirow{2}{*}{$\begin{array}{c}\text { B. allii } \\
\begin{array}{c}\text { Gray or grayish } \\
\text { brown }\end{array}\end{array}$} & \multirow{2}{*}{$\begin{array}{c}\text { B. cinerea } \\
\text { White mycelium, } \\
\text { grayish brown }\end{array}$} & \multirow{2}{*}{$\begin{array}{l}\text { B. squamosa } \\
\text { White mycelium }\end{array}$} \\
\hline Colony & Color & & & & & \\
\hline \multirow[t]{3}{*}{ Conidia } & Shape & ellipsoidal & ellipsoidal & ellipsoidal & $\begin{array}{l}\text { ellipsoidal or } \\
\text { obovoid }\end{array}$ & - \\
\hline & Length $(\mu \mathrm{m})$ & $7.6-10.4$ & $8.3-10.4$ & $9.9-14.1$ & $9.5-10.9$ & $21.0-22.5$ \\
\hline & Width ( $\mu \mathrm{m})$ & $4.2-5.6$ & $4.5-5.6$ & $5.3-6.3$ & $6.9-7.6$ & $16.5-17.0$ \\
\hline Sclerotia & & No & No & No & $\begin{array}{c}\text { Medium to large, } \\
\text { dark brown }\end{array}$ & Small, black \\
\hline
\end{tabular}

${ }^{a}$ Described by Yohalem et al., Ellis and Waller, Chilvers and Toit, and Presly

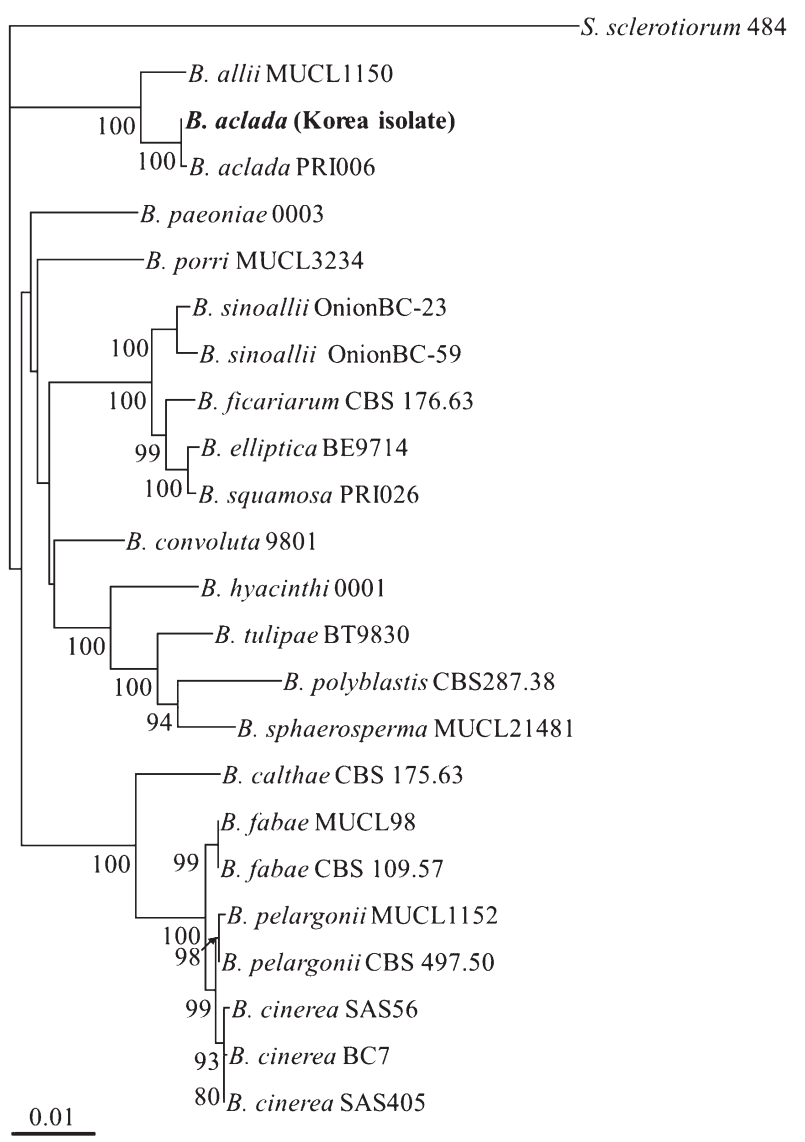

Fig. 2. Phylogenetic tree of members of the genus Botrytis, based on the combined data from G3PDH, RPB2, and HSP60. The tree was constructed using the neighbor-joining method and genetic distance was computed using Kimura's model. Sclerotinia sclerotiorum was used as an outgroup. Numbers on the branches are confidence value obtained for 100 replicates (only values above $80 \%$ are shown). The bar represents a phylogenetic distance of $1 \%$.

grayish brown and covered with abundant ellipsoidal conidia with terminal branching conidiophores (Fig. 1C and 1D). The conidia of isolates were 7.6-10.4 $\mu \mathrm{m}$ in length and $4.2-5.6 \mu \mathrm{m}$ in width, with an average dimension of $8.4 \times 5.0 \mu \mathrm{m}$. No sclerotia were produced after 30 days of incubation at $20^{\circ} \mathrm{C}$. The morphological and cultural characteristics of the isolates were similar to those of B. aclada and B. allii reported previously (Table 1) (Yohalem et al., 2003; Ellis and Waller, 1974; Chivers and Toit, 2006; Presly, 1985). However, the morphological characteristics of isolates were different from those of $B$. cinerea previously reported in Korea. To determine pathogenicity, the isolates were cultured on PDA plates for 10 days at $20^{\circ} \mathrm{C}$. Symptoms similar to those of natural infection, including water-soaked lesions with gray mycelium and conidia, were observed on the surface of onion bulbs approximately 6 to 7 days after inoculation (data not shown). No lesions were induced in the control.

\section{Phylogenetic analysis}

PCR amplification of the ITS region was performed using the primer set ITS1F/ITS4, using previously described conditions. The resulting sequences of the isolates were $100 \%$ homologous. An NCBI BLAST search showed that the ITS region sequences of the isolates were $>99 \%$ homologous with the respective sequences in $B$. cinerea and $B$. aclada. In the neighbor-joining tree using the combined gene sequence data set $(G 3 P D H$, HSP60, and RPB2), strains of seventeen species of Botrytis and the isolates formed a clade with $100 \%$ bootstrap support, compared to the outgroup fungi (S. sclerotiorum) (Fig. 2). Within the Botrytis clade, the isolates were grouped with $B$. aclada, and were closely related to $B$. allii. All sequences of $B$. aclada were deposited in Genbank (Accession No. LC079036-G3PDH; LC0790377-RPB2; LC079038-HSP60).

\section{PCR-RFLP analysis}

The isolates were grouped as described by Nielsen et al. (Fig. 3A). The isolates corresponded to B. aclada (Fig. 3B). RFLP analysis helped distinguish this particular Botrytis species as being associated with neck rot of onions, since the morphological and culture characteristics were similar to those of $B$. allii isolated in Korea. Based on the sequence of three nuclear genes $(G 3 P D H$, HSP60, and RPB2) and RFLP analysis using ApoI, the isolates obtained from rotted onion bulbs collected from the low-temperature warehouse in Changnyeong-gun 

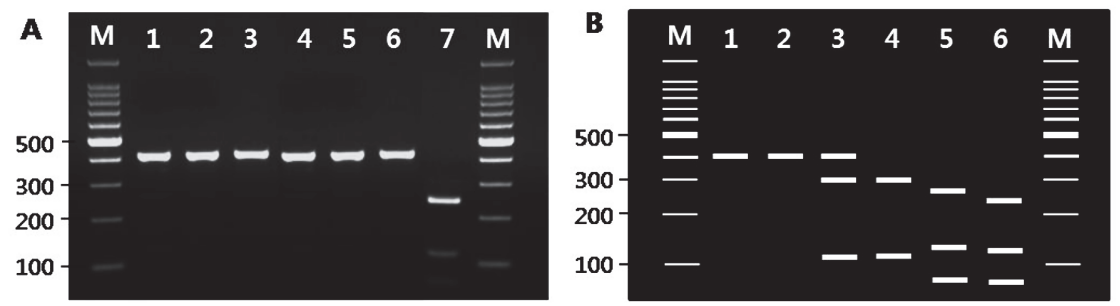

Fig. 3. ApoI restriction digest of PCR amplicons obtained using a Botrytis-specific primer set (BA2f/BA1r). A: ApoI restriction digest of the PCR amplification products: M: 100-bp ladder, lanes 1-6: isolates (this study), lane 7: B. cinerea; B: ApoI restriction digest of PCR amplification products of the isolate and other Botrytis species: M: 100-bp ladder, 1: isolate (this study), 2: B. aclada, 3: B. allii, 4: B. byssoidea, 5: B. squamosal, and 6: B. cinerea.

were identified as $B$. aclada. Although onion gray mold disease caused by B. allii, B. cinerea, and B. squamosa has previously been reported in Korea, B. aclada causing gray mold neck rot disease is a new pathogen in lowtemperature warehouses. Moreover, B. aclada was dominant to $B$. squamosa in the low-temperature warehouse. This, to the best of our knowledge, is the first report of gray mold neck rot disease caused by $B$. aclada on onion bulbs in Korea.

\section{ACKNOWLEDGEMENT}

This research was supported by a grant (NIBR 201501205) from the National Institute of Biological Resources (NIBR), funded by the Ministry of Environment (MOE) of the Republic of Korea for projects on the survey and discovery of indigenous Korean fungal species.

\section{REFERENCES}

Chilvers, M. I. and L. J. Toit 2006 Detection and identification of Botrytis species associated with neck rot, scape blight, and umbel blight of onion. Plant Health Prog., 10: 1-20

Ellis, M. G. and J. M. Waller 1974 Sclerotinia fuckeliana (conidial state: Botrytis cinerea). CMI Descr. Pathgenic Fungi Bact. No. 431 Surrey. England: Commonwealth Mycol.

Kim, Y. K., S. B. Lee, S. Y. Lee, Y. H. Lee, H. D. Kim, T. Yun and S. W. Park 2001 Ecology and control of postharvest disease of garlics and onions. In: M. N. Chung, editor. Crop protection research. Suwon, Korea: National Institute of Agricultural Science and Technology. pp. 56-89

Kim, Y. K., S. D. Lee and W. D. Cho 1998 Occurrence investigation of crop disease and pest. In: K. K. Kim, editor. Project for investigation of crop disease and pest research. Suwon,
Korea: National Institute of Agricultural Technology. pp. 5

KSPP 2009 List of plant diseases in Korea. 5th ed. Suwon, Korea: Korean Society of Plant Pathology. pp. 132-135

Lee, C. J., S. K. Lim, B. C. Kim and W. Park 2005 Characterization of bacteria isolated from rotted onion (Aliium cepa L.). Kor. J. Microbiol. Biotechnol., 33: 248-254

Nielsen, K., A. F. Justesen, D. F. Jensen and D. S. Yohalem 2001 Universally primed polymerase chain reaction alleles and internal transcribed spacer restriction fragment length polymorphisms distinguish two subgroups in Botrytis aclada distinct from B. byssoidea. Phytopathology, 91: 527-533

Nielsen, K., D. S. Yohalem and D. F. Jensen 2002 PCR Detection and RFLP differentiation of Botrytis species associated with neck rot of onion. Plant Dis., 86: 682-686

Park, S. Y., D. H. Lee, H. J. Chung and Y. J. Koh 1995 Gray mold neck rot of onion caused by Botrytis allii in Korea. Kor. J. Plant Pathol., 11: 348-352

Presly, A. H. 1985 Studies on Botrytis spp. occurring on onions (Allium cepa) and leeks (Allium porrum). Plant Pathol., $\mathbf{3 4}$ $422-427$

Saitou, N. and M. Nei 1987 The neighbor-joining method: a new method for reconstructing phylogenetic trees. Mol. Biol. Evol., 4: $406-425$

Staats, M., P. van Baarlen and J. A. van Kan 2005 Molecular phylogeny of the plant pathogenic genus Botrytis and the evolution of host specificity. Mol. Biol. Evol., 22: 333-346

White, T. J., T. Bruns, S. Lee and J. Taylor 1990 Amplification and direct sequencing of fungal ribosomal RNA genes for phylogenetics. In: Innis, M. A., D. H. Gelfand, J. J. Sninsky, T. J. White, editors. PCR protocols: a guide to methods and applications. San Diego: Academic Press pp. 315-322

Yohalem, A. S., K. Nielsen and M. Nicilaisen 2003 Taxonomic and nomenclatural clarification of the onion neck rotting Botrytis species. Mycotaxon, 85: 175-182

Zhang, J., L. Zhang, G. Q. Li, L. Yang, D. H. Jiang, W. Y. Zhuang and H. C. Huang 2010 Botrytis sinoallii: a new species of the grey mould pathogen on Allium crops in China. Mycoscience, 51: 421-431 